\title{
RESUMO
}

\section{PERFIL DE CRIANÇAS COM TRANSTORNO DO DESENVOLVIMENTO DA COORDENAÇÃO EM TAREFAS DE TIMING}

\author{
Autor: LUIZ EDUARDO PINTO BASTO TOURINHO DANTAS \\ Orientador: Prof. Dr. EDISON DE JESUS MANOEL
}

Esse trabalho tem como foco a condição mencionada acima, nomeada como Transtorno do Desenvolvimento da Coordenação (TDC) pela AMERICAN PSYCHIATRIC ASSOCIATION - DSM - IV (2002) e Transtorno específico do desenvolvimento motor, pela ORGANIZAÇÃO MUNDIAL DA SAÚDE - CID-10 (1993). Foi discutido que a base da classificação usada nas pesquisas acerca desse transtorno tem como finalidade primária o diagnóstico clínico, e também apontado as conseqüências desse tipo de definição para orientação de pesquisas. A heterogeneidade das amostras de TDC utilizadas em pesquisas prévias pode ser vista como um obstáculo à própria investigação do fenômeno. Foi explorada uma possibilidade de superar esse problema através de uma abordagem diferencial, na qual se buscou diferença na capacidade de organização temporal do movimento (timing) dentro da própria população que sofre desse transtorno, na tentativa de caracterizar grupos com maior homogeneidade. Para isso 44 sujeitos, entre 9 e 11 anos, foram selecionados com base no seu desempenho do teste MABC (HENDERSON \& SUGDEN, 1992), sendo 20 sujeitos com TDC e 24 normais. Esses sujeitos foram submetidos a uma bateria de tarefas de timing para caracterizá-los. As variáveis foram analisadas conjuntamente através de uma análise de clusters. O exame do coeficiente de fusão e observação do dendograma sugeriu a partição em dois clusters. Os resultados mostraram que os sujeitos com TDC agrupados em cada 
uma dos clusters podem ser caracterizados com relação apenas ao timing sincronizório. As demais variáveis de timing não discriminam os dois subgrupos.

Palavras-chave: Transtorno do Desenvolvimento da Coordenação, Timing, Coordenação.

\title{
ABSTRACT
}

PERFIL DE CRIANÇAS COM TRANSTORNO DO DESENVOLVIMENTO DA COORDENAÇÃO EM TAREFAS DE TIMING

\author{
Author: LUIZ EDUARDO PINTO BASTO TOURINHO DANTAS \\ Adviser: PROF.DR. EDISON DE JESUS MANOEL
}

The focus of this study was the condition above mentioned, named Developmental Coordination Disorder (DCD) by the AMERICAN PSYCHIATRIC ASSOCIANTION - DSM - IV (2002) and by WORLD HEALTH ORGANIZATION CID - 10 (1993). It was discussed that the purpose of the classification DSM - IV and CID - 10 is to guide the clinical diagnostic, and pointed out the implications of this criteria to orient how to select subjects in the researches. The heterogeneity of the DCD samples used in previous researches can be seen as a hindrance to investigating the problem itself. To try to overcome that obstacle, a differential approach was used, in which the difference in timing within the population who suffers that disorder was searched for, in order to characterize more homogenous groups. We selected 44 children, ranging from 9 to 11 years old, based on their performance 
in the MABC test (HENDERSON \& SUGDEN, 1992), being 20 children with DCD and 24 without it (normal). The variables are analyzed together through a clusters analyzes. Examination of the fusion coefficients and the cluster dendogram suggested two groups. The results suggested that the DCD subjects who were grouped in each of the clusters can be characterized by their performance in the synchronic timing tasks only. The other timing variables do not discriminate the two subgroups.

Keywords: Developmental Coordination Disorder, Timing, Coordination 